\title{
Relative abundances of medium and large mammals in the Cueva de Los Guácharos National Park (Huila, Colombia)
}

\author{
Felipe Gast ${ }^{1, * \mathbb{D}}$ \& Pablo R. Stevenson ${ }^{1}$ (1) \\ ${ }^{1}$ Universidad de los Andes, Facultad de Ciencias, Bogotá Colombia. \\ *Corresponding author: Felipe Gast, e-mail: felogast@hotmail.com
}

GAST, F., STEVENSON, P.R. Relative abundances of medium and large mammals in the Cueva de Los Guácharos National Park (Huila, Colombia). Biota Neotropica 20(3): e20160305. https://doi.org/10.1590/16760611-BN-2016-0305

\begin{abstract}
Medium and large mammals are greatly affected by human activities, such as, habitat loss and hunting. In Colombia, these pressures have been most extensive in the dry and Andean forests. However, there is scare information available on the presence or abundance of these organisms for monitoring purposes. This study used photo-trapping cameras to determine the relative abundances of medium and large mammals in a mountain forest in the National Natural Park "Cueva de los Guacharos", Huila (Colombia). Additionally, we examined whether trail use by humans could affect the distribution of these organisms. The cameras were located every 500 meters along the trails in strategic locations. We obtained the relative abundance of 11 species, being medium-sized mammals the most frequent (Cuniculus paca, Dasyprocta punctata and Mazama rufina). We recorded the presence of mountain tapir (Tapirus pinchaque), dwarf red brocket (Mazama rufina) and oncilla (Leopardus tigrinus), which are found in a high threat category according to the IUCN. Activity patterns were reported for 4 different species including daytime, nocturnal and cathemeral activities. Finally, we concluded that large mammals avoided trails of frequent use, and although the relative abundance of mammals is not very high, this National Park is still supporting relevant biodiversity.
\end{abstract}

Keywords: Camera-traps; endangered species; Mammalia; activity patterns.

\section{Abundância relativa dos mamíferos de médio e grande porte no Parque Nacional Cueva de Los Guácharos (Huila, Colômbia)}

Resumo: Os mamíferos de porte médio e grande são fortemente afetados por atividades humanas, tais como a perda do seu habitat e a caça. Na Colômbia, essas pressões foram mais extensas em florestas secas e andinas. No entanto, há pouca informação disponível sobre a presença ou abundancia destes organismos para os processos de monitoramento. Este estudo usou câmeras com mecanismos remotos de "armadilhas-fotográficas" (photo-trapping) para determinar a abundância relativa de mamíferos de porte médio e grande numa floresta de montanha no Parque Nacional Natural "Cueva de los Guacharos", Huila Colômbia. Adicionalmente, examinamos se o uso das trilhas pelos humanos poderia afetar a distribuição destes organismos. As câmeras foram localizadas a cada 500 metros ao longo das trilhas e em locais estratégicos. Obtivemos a abundância relativa de 11 espécies, sendo os mamíferos de médio porte os mais frequentes (Cuniculus paca, Dasyprocta punctata and Mazama rufina). Se registrou a presença do tapir da montanha (Tapirus pinchaque), do veado vermelho (Mazama rufina) e do gato-do-mato (Leopardus tigrinus), que fazem parte da categoria de espécies em ameaça de acordo com a IUCN. Os padrões de atividade das 4 espécies diferentes foram relatados, incluindo atividades diurnas, noturnas e atividades cathemeral. Por fim, concluiu-se que os grandes mamíferos evitam as trilhas de uso frequente, e embora a abundância relativa de mamíferos não seja muito alta, este parque nacional ainda tem uma biodiversidade proeminente.

Palavras-chave: Câmeras de foto-caça; padrões de atividade; espécies ameaçadas de extinção; Mammalia. 


\section{Introduction}

The tropical Andes is a region with great biological diversity. Unfortunately, the area is facing great deterioration of the habitat by anthropic intervention, such as, deforestation for agriculture and livestock (Rodríguez et al. 2012, Rodriguez et al. 2013). Currently, conservation strategies in this region are based on national and private reserves, which cover about $10 \%$ of the terrestrial area. Andean and sub-Andean forests are the most affected ecosystems, while the paramo is the most protected (Armenteras et al. 2003). Despite these efforts, the situation in national reserves is not optimal, there are high rates of deforestation in National Parks of Colombia (Etter et al. 2006, Miller et al. 2004). For instance, recent years have shown a clear deterioration of the natural areas in the buffer zone of the Cueva de los Guácharos Natural Park (PNNCG) (Hurtado 2013). This phenomenon may be causing problems in population dynamics of organisms that inhabit these areas both by hunting (Roldán and Simonetti 2001) and habitat reduction.

Some medium and large mammals can be considered as keystone species in their ecosystems, since, they play an important role as predators and seed dispersers (Jansen et al. 2012, Terborgh et al. 2001). For example, herbivorous species, as part of trophic networks at intermediate levels, can affect plant populations and control densities of other species, as predators (Terborgh \& Wright 1994, Kelly \& Holub 2008, Lizcano \& Cavelier 2004). Its effect can be so great that it is considered possible that there is a direct relation in the floristic composition of the forest in future years, when the density or presence of certain mammal species in the area changes (Roldán \& Simonetti 2001). These effects are difficult to measure and depend on the population density (Stevenson 2011).

There are few cases of mammal hunting in Colombia's national parks. Fortunately, no massive logging or crop events were identified for more than 30 years in Cueva de Los Guacharos National Park (UAESPNN 2005), which is our study site. However, given the continuous advance of the agricultural frontier in the surroundings of the park, we should consider a possible increase on hunting pressure for the coming years, generating displacement of individuals by the deterioration of their habitat. For these reasons, it is of great importance to know the current status of the populations of mammals. Studies of relative abundance are very important for the detection of changes in wildlife population dynamics (Lyra-Jorge et al., 2008). This information can be used to make decisions about management and conservation of a specific population or area. According to the management plan of the PNNCG, within and at its surroundings there are 59 species of mammals, belonging to 11 orders and 25 families. The orders with the greatest relative abundance of species are Chiroptera, Carnivora and Rodentia (UAESPNN 2005), mostly small individuals, which are not the focus of this study. In terms of large and medium-sized mammals, there is a list of species such as the mountain tapir (Tapirus pinchaque), the spectacled bear (Tremarctos ornatus), the dwarf red brocket (Mazama rufina) and the northern pudu (Pudu mephistophiles) most of them at risk of extinction (UAESPNN 2005). However, some of these species, such as the mountain tapir, has not been recorded in recent years. The threat status of the different species presented in the management plan of the PNNCG was obtained from the International Union for Conservation of Nature's Red List of Threatened Species better known as the IUCN red list (IUNC, 2005). This is the world's most comprehensive information source on the global extinction risk status of different species in the world.
It provides information about range, population size, habitat and ecology, threats and conservation actions for a vast number of species worldwide. Thus, the IUCN red list is an important tool to make informed conservation decisions.

The study of terrestrial mammals is a difficult and laborious task. Since, they are elusive animals with large ranging areas, and usually difficult to observe or follow (Yasuda 2004). For these reasons tracking techniques such as footprints and direct observation have been used on studies of relative abundance and distribution of medium and large mammals (Olifiers et al., 2011). However, in some cases the determination of tracks is ambiguous (Emmons 1997). In consequence, it is very useful to use monitoring techniques that make identification at the species level easier (Yasuda 2004). Monitoring mammals using camera traps is one of the most successful, non-invasive methods that includes identification of species with cryptic habits (Silveira et al., 2003, Treves et al., 2010). This method with a proper sampling design can provide detailed and continuous information on the state of the populations (Ahumada et al., 2011, Silveira et al., 2003). For some years, the use of camera traps has allowed the estimation of mammalian populations, being more commonly used in felids (Soria-Diaz et al., 2010, Silver et al., 2004, Wang \& Macdonald 2009).

For this study it is argued that human presence, even if they are not hunters, affects the habitat use of mammals. According with this idea, it is expected to find higher rates of sighting on trails with little human use, at least for large mammals, since these tend to avoid places with anthropic activity. In addition, the information generated in this study is expected to become a reference for conservation measurements at the national park.

\section{Materials and Methods}

\section{Area of study}

The study was carried out in Cueva de los Guácharos National Park (PNNCG), located in the departments of Huila and Caquetá (Colombia) $1^{\circ} 36^{\prime} 56.0^{\prime \prime} \mathrm{N}, 76^{\circ} 06^{\prime} 08.5^{\prime}$ ' $\mathrm{W}$. Total area is 9,000 ha, with elevations between 1700 and 3000 masl. The park has an annual average temperature of $16^{\circ} \mathrm{C}$ with an annual average rainfall of 3,100 $\mathrm{mm}$ and a relative humidity of $87 \%$. In 1980 , UNESCO declared it a Biosphere Reserve (UAESPNN 2005).

\section{Setting of the cameras}

A total of 18 camera traps (Cuddeback Capture model) were used. These operated 24 hours a day, and were programmed with an interval of 30 seconds between events. The cameras were set at a distance of approximately $500 \mathrm{~m}$ between them and were located in existing trails taking into account the use of these to see if there were differences between places with greater human traffic $(n=8$ cameras) and trails that were not used frequently $(n=9)$ defined as those who have less than a weekly visit by officials, visitors or researchers. In addition, a camera was placed in a cave inhabited by oilbirds (Steatornis caripensis), which is a very busy place visited by tourists $(\mathrm{n}=1)$. In this place colonies of oilbirds discharge many seeds, which can be a mammalian food resource. Each of the cameras was installed at a height of $40 \mathrm{~cm}$ from the ground. The study was carried out between elevations of 1940 and 2340 masl. The cameras were checked every two months by changing the batteries and memory card for a total of 14 months of sampling. 


\section{Data analysis}

When analyzing the obtained photos, each animal occurrence was taken as a sighting, except photos of the same species taken with a difference of less than 30 minutes, which were taken as a single sighting, since the probability of capturing the same individual is very high (O'Brien 2010). A medium-sized mammal was considered to have a weight between $250 \mathrm{~g}$ and $4 \mathrm{~kg}$, while large mammals were considered greater than $4 \mathrm{~kg}$. With the obtained images, we estimated the relative abundances of each mammal species. The relative abundance of mammals was calculated by taking into account the number of times an individual was recorded and assuming that all individuals are equally likely to be recorded (Springer et al., 2012), as well as the total number of night traps (O’Brien 2010).

$$
\text { Encounter } \operatorname{Index}(I)=\left(\frac{\text { number of records of the species }}{\text { number of nights trap }}\right)
$$

$$
\text { Relative abundance per night } \operatorname{trap}(A R 1)=\mathrm{I} * 100
$$

Species were classified as diurnal, nocturnal or cathemeral (van Schaik \& Griffiths 1996). Activity patterns were estimated only for species that were recorded at least eleven independent times (Monroy-Vilchis et al., 2011). Graphs were made in the Oriana program, which allow seeing the patterns of activity in a circular way (Kovach Computing Services 2004).
Statistical tests Mann-Whitney and Kruskal-Wallis obtained using R software (R-Development-Core- Team 2008), were used to evaluate statistical differences between trails with different frequencies of use.

\section{Results}

With a total of 3595 night traps, 176 records of mammal belonging to 11 species were obtained (Table 1). Within the list of species, and according to the IUCN criteria some of the species found were at high threat level such as the mountain tapir (Tapirus pinchaque), which was in the endangered category. Other mammals such as the spectacled bear (Tremarctos ornatus), the oncilla (Leopardus tigrinus) and the dwarf red brocket (Mazama rufina) with vulnerable category (VU) were also registered. The rest of the registered species were in the least concern category (LC).

Obtained relative abundances showed higher values for medium mammals such as Cuniculus paca and Dasyprocta punctata, followed by large mammals, with species such as M. rufina, Puma concolor and T. ornatus (Fig. 1). For relative abundance recorded in the different type of trails, it was observed that; taking into account all species recorded in the study there was no significant differences (Mann-Whitney: $U$ $=2000, P=0.228$ ). However, by discriminating by size category, the results suggest that only large mammals were sensitive to the use of trails by humans $(\mathrm{M}-\mathrm{W}: \mathrm{U}=0.0, \mathrm{P}=0.049)$. Median mammals do not showed statistically significant results $(\mathrm{M}-\mathrm{W}: \mathrm{U}=36.50, \mathrm{P}=0.7341)$.

Table 1. Species registered by trap-cameras in Cueva de Los Guacharos National Park (Colombia), including number of records, the IUCN threat category, encounter

\begin{tabular}{|c|c|c|c|c|c|c|}
\hline $\begin{array}{l}\text { Family } \\
\text { Species }\end{array}$ & Local name & Records & IUCN & I & AR 1 & Trail type \\
\hline \multicolumn{7}{|l|}{ Sciuridae } \\
\hline \multicolumn{7}{|l|}{ Cuniculidae } \\
\hline Sapajus apella & maicero & 1 & $\mathrm{LC}$ & 0,0003 & 0,03 & NF \\
\hline \multicolumn{7}{|l|}{ Tapiridae } \\
\hline Tapirus pinchaque & danta & 2 & EN & 0,0006 & 0,06 & $\mathrm{NF}$ \\
\hline \multicolumn{7}{|l|}{ Didelphidae } \\
\hline \multicolumn{7}{|l|}{ Dasyproctidae } \\
\hline Dasyprocta punctata & ñeque & 44 & $\mathrm{LC}$ & 0,0122 & 1,22 & $\mathrm{~F}-\mathrm{NF}$ \\
\hline \multicolumn{7}{|l|}{ Ursidae } \\
\hline Tremarctos ornatus & oso & 8 & VU & 0,0022 & 0,22 & NF \\
\hline \multicolumn{7}{|l|}{ Felidae } \\
\hline Puma concolor & puma & 19 & $\mathrm{LC}$ & 0,0053 & 0,53 & F-NF \\
\hline Leopardus tigrinus & tigrillo & 1 & VU & 0,0003 & 0,03 & $\mathrm{NF}$ \\
\hline \multicolumn{7}{|l|}{ Cervidae } \\
\hline Mazama rufina & venado & 40 & VU & 0,0111 & 1,11 & NF \\
\hline
\end{tabular}
rate, relative abundance, and the type of trail where they were found ( $\mathrm{F}$ trails of frequent use by humans and NF trails with less use). 
The difference of each trail individually did not present significant statistical differences (Kruskal-Wallis $=9.2, \mathrm{P}=0.13$ ).

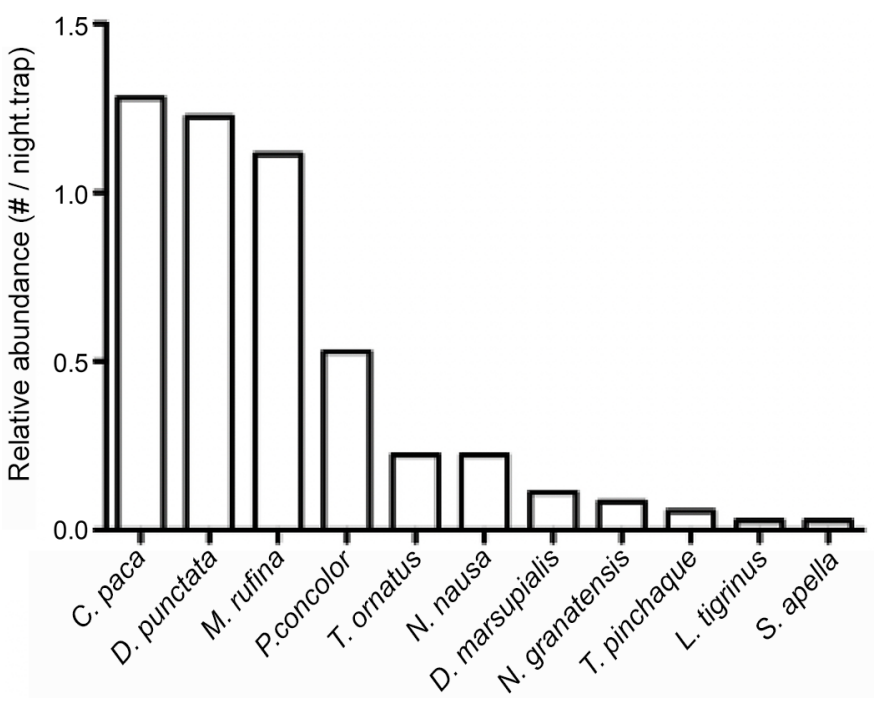

Figure 1. Relative abundance for each species.
Activity patterns for four species were found, including diurnal (D. punctata), nocturnal (C. paca), and cathemeral (P. concolor and M. rufina) (Fig. 2).

\section{Discussion}

The use of the trails by humans affected the distribution of large mammals, since they were detected less frequently in commonly used trails. The puma ( $P$. concolor) proved to be the only large mammal recorded on transit trails. Although the park is in a good state of conservation, it is important to maintain a large buffer area, as it has been observed that the greater the fragmentation the lower density of mammals inhabit a place (Ahumada et al., 2011).

The proportion between large and medium mammals is expected since it coincides with previous findings where medium mammals such as $C$. paca and D. punctata tend to show higher relative abundances than other species such as predators (Arcos 2010). Median mammals reported are in many cases the potential prey of large carnivorous mammals, such as $P$. concolor (Hernández-Guzmán et al., 2011).

When comparing results with the ones reported in bibliography, this study indicate one of the places with the lowest number of species
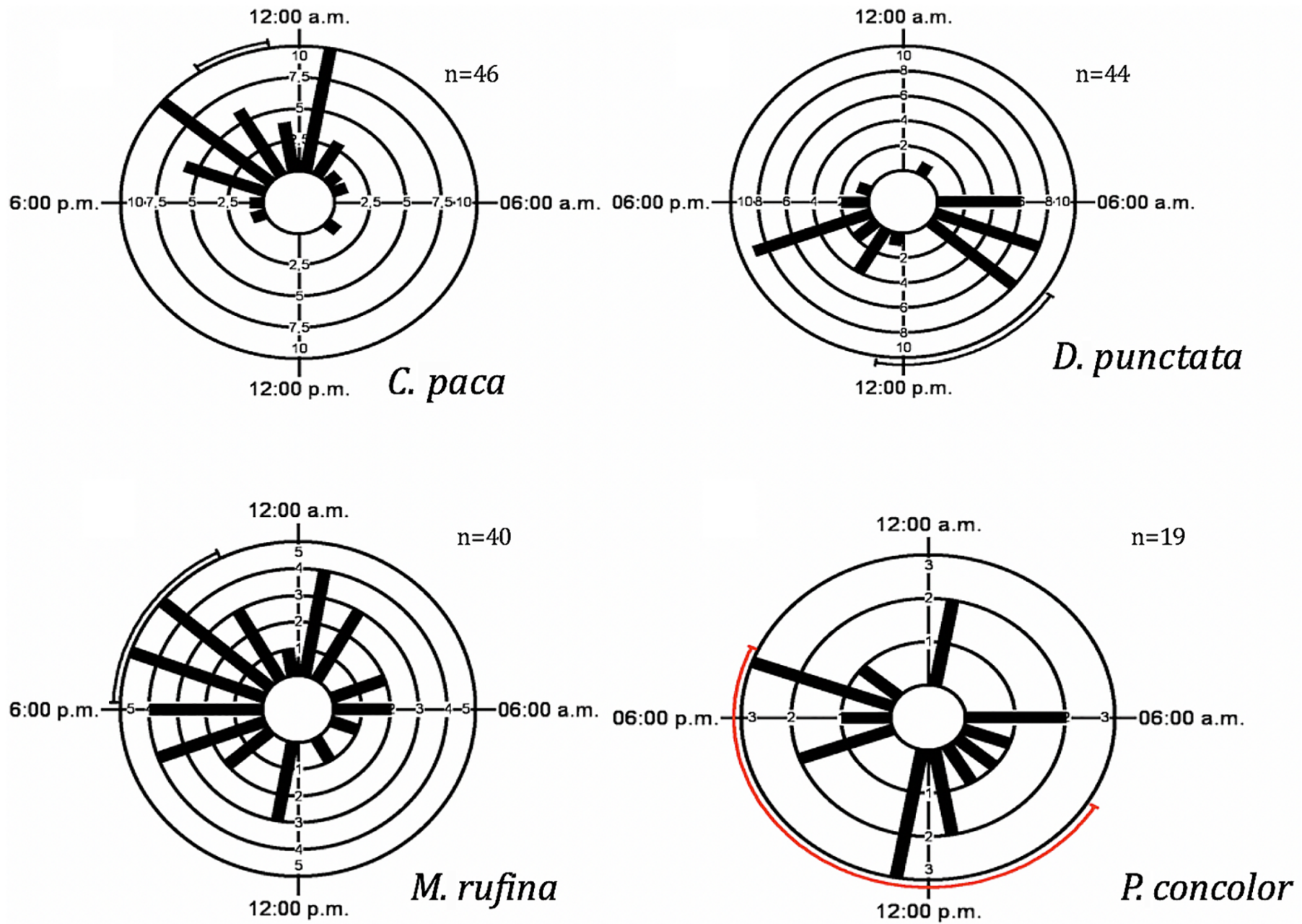

Figure 2. Activity patterns of mammal species showing at least 7 sightings in Cueva de Los Guacharos National Park (Colombia). a: lowland paca (C. paca), b: agouti (D. punctata), c: dwarf red brocket (M. rufina), d: puma (P. concolor). The red line in the graph of puma indicates no specific trend for the hours in which this is active. 
(Lira-Torres \& Briones-Salas 2012, Botelho et al., 2012, Ahumada et al., 2011). It is important to realize that most of the studies have been carried out in lowland forests, which have higher productivity, and greater number of species. Similar diversity and abundance of species are reported in the Andes mountain range, for example in Ecuador (Arcos, 2010).

Regarding to the activity of different species, the lack of a clear pattern in the activity of the puma ( $P$. concolor), which can have daytime and nighttime activity, could indicate a good state of conservation of the area, since in places with greater human and hunting presence, these tend to decrease their diurnal activity (Paviolo et al., 2009). In the same way, it is possible to observe how the periods of more records coincide with the activity peaks of some species that are common prey of the puma, such as M. rufina, C. paca, and D. punctata. As previously mentioned, the abundance of these prey species is higher than that of the predator (Foster et al., 2013).

The finding of the mountain tapir (T. pinchaque) and the spectacled bear (T. ornatus) is a very positive fact, since these species are highly affected by hunting. Their densities tend to be small, being the tapir one of most affected by this threat (Cavelier et al., 2011). Tapirs have shown an important role as herbivores and some consider them important seed dispersers, which help to infer that the area is in a good state of conservation (Downer, 2001).

We conclude that the use of trails by humans can affect the presence of large mammals, something to consider when choosing conservation and study areas. The PNNCG has priority species for conservation. Although the relative abundances of some of these, such as the paramo tapir, are low, their presence is an indicator that the park still has a good state of conservation, since in general these are individuals very sensitive to anthropic activities. The PNNCG has been open to scientific research; however, this was the first study using camera traps, which allows to complement the catalog of fauna that has been observed. In addition, information on the relative abundance of terrestrial mammals may allow future monitoring. We hope that these data can be useful in the elaboration of conservation actions, management plans and other scientific studies.

\section{Supplementary material}

The following online material is available for this article:

Appendix - Photographs of some of the species recorded during the study in Cueva de Los Guacharos National Park (Colombia).

\section{Acknowledgments}

We want to thank all the people who were involved in some way in the process of this research, especially The Universidad de los Andes, the members of the LEBTYP for their support in the field and in the analysis of data. Abelardo Rodríguez Bolaños for advice and support in the identification of mammals. Laura Garza for the help reviewing the document. Finally, to Carlos Cortes and the rest of the park staff that collaborated in the field stage as well as the Park Unit for allowing the completion of the work.

\section{Author Contributions}

Felipe Gast: Substantial contribution in the concept and design of the study. Contribution to data collection. Contribution to data analysis and interpretation. Contribution to manuscript preparation. Contribution to critical revision, adding intellectual content.

Pablo R. Stevenson: Substantial contribution in the concept and design of the study. Contribution to data analysis and interpretation. Contribution to manuscript preparation. Contribution to critical revision, adding intellectual content.

\section{Conflicts of Interest}

The authors declare that they have no conflict of interest related to the publication of this manuscript.

\section{References}

AHUMADA, J. A., SILVA, C. E. F., GAJAPERSAD, K., HALlAM, C., HURTADO, J., MARTIN, E., ANDELMAN, S. J. 2011. Community structure and diversity of tropical forest mammals: data from a global camera trap network. Philosophical Transactions of the Royal Society B: Biological Sciences, 366(1578), 2703-2711. doi:10.1098/rstb.2011.0115

ARCOS, R. G. 2010. Riqueza y abundancia relativa de mamíferos en la Cordillera Oriental Yacuambi, en el suroriente ecuatoriano. Serie Zoológica, 6(9), 147-161.

ARMENTERAS, D., GAST, F., \& VILLAREAL, H. 2003. Andean forest fragmentation and the representativeness of protected natural areas in the eastern Andes, Colombia. Biological Conservation, 113(2), 245-256. doi:10.1016/S0006-3207(02)00359-2

Botelho, A. L., CAlouro, A. M., BORGES, L. H., \& CHAVES, W. A. 2012. Large and medium-sized mammals of the Humaitá Forest Reserve, southwestern Amazonia, state of Acre, Brazil. CheckList, 8(6).

CAVELIER, J., LIZCANO, D., YERENA, E., \& DOWNER, C. 2011. The mountain tapir (Tapirus pinchaque) and Andean bear (Tremarctos ornatus): two charismatic, large mammals in South American tropical montane cloud forests. En Tropical Montane Cloud Forests. Cambridge University Press. Recuperado a partir de http://dx.doi.org/10.1017/CBO9780511778384.019

DOWNER, C. C. 2001. Observations on the diet and habitat of the mountain tapir (Tapirus pinchaque). Journal of Zoology, 254(03), 279-291. doi:10.1017/ S0952836901000796

EMMONS, L. 1997. Neotropical rainforest mammals: a field guide (2nd ed., p. 307). Chicago: University of Chicago Press.

ETTER, A., MCALPINE, C., PHINN, S., PULLAR, D., \& POSSINGHAM, H. 2006. Characterizing a tropical deforestation wave: a dynamic spatial analysis of a deforestation hotspot in the Colombian Amazon. Global Change Biology, 12(8), 1409-1420.

FOSTER, R. J., \& HARMSEN, B. J. 2012. A critique of density estimation from camera-trap data. The Journal of Wildlife Management, 76(2), 224-236. doi:10.1002/jwmg. 275

FOSTER, V. C., SARMENTO, P., SOLLMANN, R., TÔRRES, N., JÁCOMO, A. T. A., NEGRÕES, N., SILVEIRA, L. 2013. Jaguar and puma activity patterns and predator-prey interactions in four Brazilian biomes. Biotropica. doi:10.1111/btp.12021

HERNÁNDEZ-GUZMÁN, A., PAYÁN, E., \& MONROY-VILCHIS, O. 2011. Hábitos alimentarios del Puma concolor (Carnivora: Felidae) en el Parque Nacional Natural Puracé, Colombia. Revista de Biología Tropical, 59 (3), 1285-1294

HURTADO A. 2013. ¿Joya en peligro?, see http://www.eltiempo.com/opinion/ columnistas /andreshurtadogarcia/joya-en-peligro-_12942605-4 (accessed 22 january 2014),

IUCN. 2005 IUCN Red List of Threatened Species. See http://www.iucnredlist.org. 
JANSEN, P. A., HIRSCH, B. T., EMSENS, W.-J., ZAMORA-GUTIERREZ, V., WIKELSKI, M., \& KAYS, R. 2012. Thieving rodents as substitute dispersers of megafaunal seeds. Proceedings of the National Academy of Sciences USA, 109(31), 12610-12615. doi:10.1073/pnas.1205184109

KELLY, M. J., \& HOLUB, E. L. 2008. Camera trapping of carnivores: trap success among camera types and across species, and habitat selection. Northeastern Naturalist, 15(2), 249-262. doi:10.1656/1092-6194

KOVACH COMPUTING SERVICES [ONLINE]. 2004. Oriana software. Version 2.0

LIZCANO, D. J., \& J. CAVELIER. 2004. Características químicas de salados y hábitos alimenticios de la danta de montaña (Tapirus pinchaque Roulin, 1829) en los Andes Centrales de Colombia. Mastozoologia Neotropical 11:193-201.

LIRA-TORRES, I., \& BRIONES-SALAS, M. 2012. Abundancia relativa y patrones de actividad de los mamíferos de los Chimalapas, Oaxaca, México. Acta zoológica mexicana, 28(3), 566-585.

LYRA-JORGE, M. C., CIOCHETI, G., PIVELLO, V. R., \& MEIRELLES, S. T. 2008. Comparing methods for sampling large- and medium-sized mammals: camera traps and track plots. European Journal of Wildlife Research, 54(4), 739-744. doi:10.1007/s10344-008-0205-8

MILLER, L., SAVAGE, A., \& GIRALDO, H. 2004. Quantifying remaining forested habitat within the historic distribution of the cotton-top tamarin (Saguinus oedipus) in Colombia: Implications for long-term conservation. American Journal of Primatology, 64(4), 451-457.

MONROY-VILCHIS, O., ZARCO-GONZÁLEZ, M. M., \& RODRÍGUEZSOTO, C. 2011. Fototrampeo de mamíferos en la Sierra Nanchititla , México : Abundancia relativa y patrón de actividad. Revista de Biología Tropical, 59(March), 373-383.

O’BRIEN, T. G. 2010. Wildlife picture index: implementation manual version 1.0. Wildife Conservation Society Working Papers, (39), 1285-129.

OLIFIERS, N., LORETTO, D., RADEMAKER, V., \& CERQUEIRA, R. 2011. Comparing the effectiveness of tracking methods for medium to large-sized mammals of Pantanal. Zoologia (Curitiba), 28(2), 207-213. doi:10.1590/ S1984-46702011000200008

PAVIOLO, A., DI BLANCO, Y. E., DE ANGELO, C. D., \& DI BITETTI, M. S. 2009. Protection Affects the Abundance and Activity Patterns of Pumas in the Atlantic Forest. Journal of Mammalogy, 90(4), 926-934. doi:10.1644/08

R-DEVELOPMENT-CORE-TEAM (2008) R: a language and environment for statistical computing. R Foundation for Statistical Computing, Vienna, Austria. Available at http://www.R-project.org.

RODRÍGUEZ ERASO, N., ARMENTERAS-PASCUAL, D., \& RETANA ALUMBREROS, J. 2012. Land use and land cover change in the Colombian Andes: dynamics and future scenarios. Journal of Land Use Science, 1-21. doi:10.1080/1747423X.2011.650228

RODRÍGUEZ, N., ARMENTERAS, D., \& RETANA, J. 2013. Effectiveness of protected areas in the Colombian Andes: deforestation, fire and land-use changes. Regional Environmental Change, 13(2), 423-435.
ROLDÁN, A. I., \& SIMONETTI, J. A. 2001. Interacciones PlantaAnimal en Bosques Tropicales Bolivianos Bajo Distintas Presiones de Cacería. Conservation Biology, 15(3), 617-623. doi:10.1046/j.15231739.2001.015003617.x

SILVEIRA, L., JÁCOMO, A. T. A., \& DINIZ-FILHO, J. A. F. 2003. Camera trap, line transect census and track surveys: a comparative evaluation. Biological Conservation, 114(3), 351-355. doi:10.1016/S0006-3207(03)00063-6

SILVER, S. C., OSTRO, L. E. T., MARSH, L. K., MAFFEI, L., NOSS, A. J., KELLY, M. J., ... AYALA, G. 2004. The use of camera traps for estimating jaguar Panthera onca abundance and density using capture/recapture analysis. Oryx, 38(02), 148-154. doi:10.1017/S0030605304000286

SORIA-DIAZ, MONROY-VILCHIS, O., RODRIQUEZ-SOTO, C., ZARCOGONZALES, M. M., \& URIOS, V. 2010. Variation of abundance and density of Puma concolor in zones of high and low concentration of camera traps in Central Mexico. Animal Biology, 60(4), 361-371.

SPRINGER MT, CARVER AD, NIELSEN CK, CORREA NJ, ASHMORE JR, ASHMORE JR \& LEE JG. 2012. Relative abundance of mammalian species in a central Panamanian rainforest. Latin American Journal of Conservation 2 (2) -3 (1): 19-26.

STEVENSON, P. R. 2011. The abundance of large ateline monkeys is positively associated with the diversity of plants regenerating in neotropical forests. Biotropica, 43(4), 512-519. doi:10.1111/j.1744-7429.2010.00708.x

TERBORGH, J., LOPEZ, L., NUNEZ, P., RAO, M., SHAHABUDDIN, G., ORIHUELA, G., LAMBERT, T. D. 2001. Ecological meltdown in predatorfree forest fragments. Science, 294(5548), 1923-1926.

TERBORGH, J., \& WRIGHT, S. J. (1994). Effects of mammalian herbivores on plant recruitment in two neotropical forests. Ecology, 75(6), 1829-1833. doi:10.2307/1939641

TREVES, A., MWIMA, P., PLUMPTRE, A. J., \& ISOKE, S. 2010. Cameratrapping forest-woodland wildlife of western Uganda reveals how gregariousness biases estimates of relative abundance and distribution. Biological Conservation, 143(2), 521-528. doi:10.1016/j.biocon.2009.11.025

UAESPNN. 2005. Plan de manejo Parque Natural Nacional Cueva de los Guacharos.

Unidad administrativa especial de sistemas de Parques Nacionales Naturales, 1 .

VAN SCHAIK, C. P.; GRIFFITHS, M. 1996. Activity periods of Indonesian rain forest mammals. Biotropica, 28(1), 105-112.

WANG, \& MACDONALD, D. 2009. The use of camera traps for estimating tiger and leopard populations in the high altitude mountains of Bhutan. Biological Conservation, 142(3), 606-613. doi:10.1016/j.biocon.2008.11.023

YASUDA, M. 2004. Monitoring diversity and abundance of mammals with camera traps: a case study on Mount Tsukuba, central Japan. Mammal Study, 29(1), 37-46. doi:10.3106/mammalstudy.29.37

Received: 04/11/2019

Revised: 09/05/2020

Accepted: 12/05/2020

Published online: 18/01/2021 